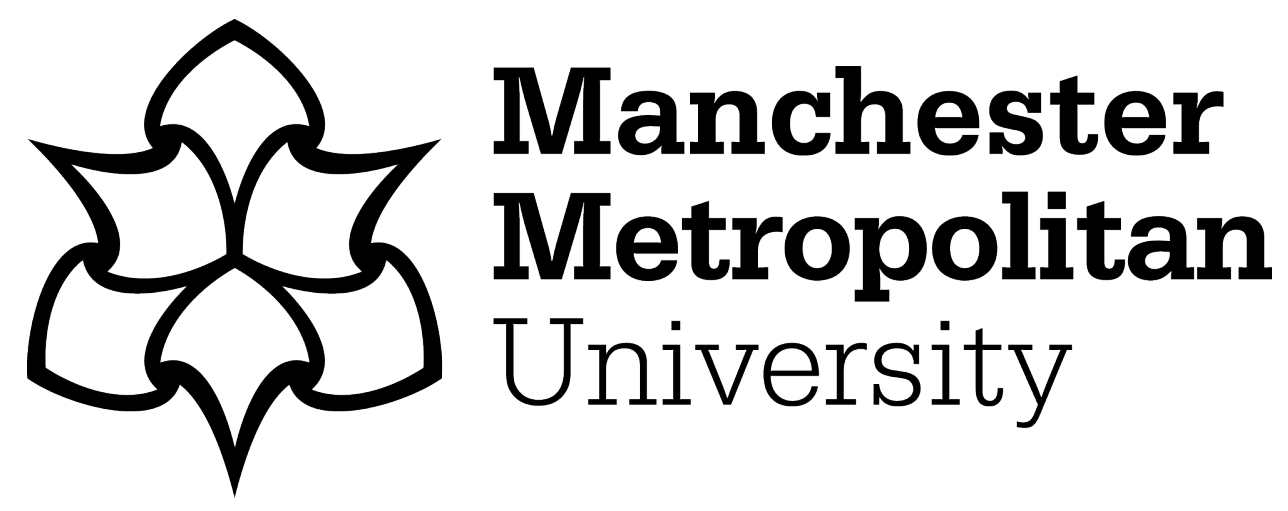

Drake, Philip (2019) From Co-productions to 'Co-distributions'? Reevaluating Distribution Policies for European Film. In: European Film and Television Co-production Policy and Practice. Palgrave Macmillan. ISBN 3319971565

Downloaded from: https://e-space.mmu.ac.uk/624783/

Version: Accepted Version

Publisher: Palgrave Macmillan

DOI: https://doi.org/10.1007/978-3-319-97157-5_5

Please cite the published version 


\section{From Co-productions to 'Co-distribution'
Re-evaluating Distribution Policies for European Film}

This chapter explores the relationship between European co-production and distribution, and examines European policies designed to support film distribution including digital and VoD distribution. According to a European Audiovisual Observatory report, more than 18,000 films were produced in Europe between 2007 and 2016, with overall production on the continent growing by $47 \%$, from 1444 feature films in 2007 to 2124 films in 2016 (Talavera 2017, 1). This notes an upward trend for most of the period for both national productions and co-productions, and the top five producing European countries - the UK, France, Germany, Spain and Italy-accounted for $53.6 \%$ of overall production in the 36 countries covered in the analysis (ibid., 16). This is concentrated, with the top 10 producing countries accounting for $73 \%$ of all films produced (ibid., 1). Within Europe, as I will examine, both the European Commission and Council of Europe have operated a range of production, co-production, 19 distribution and exhibition schemes aimed to protect against US domi- 20 nance of global screens, and to support and stimulate the production, 21 distribution and exhibition of European cinema. The premise of these 22

P. Drake $(\bowtie)$

Queen Margaret University, Edinburgh, UK

(C) The Author(s) 2018

J. Hammett-Jamart et al. (eds.), European Film and Television

Co-production, Palgrave European Film and Media Studies, https://doi.org/10.1007/978-3-319-97157-5_5 
programmes is that there is a need for supranational co-ordination, that the weakness (relative to the US) of European cinema and television derives from its relatively small-scale and dispersed nature, and that without co-ordination and support there is no 'European industry' but rather a collection of disparate national industries. European nation states are therefore encouraged to harmonise their media support structures, and use these to scale up production and co-production activities.

On the basis of the above figures, one could reasonably conclude that European film production is healthy-but what about distribution and exhibition? In analysis of European cinema most focus has been placed on film production and co-production - see other chapters in this volumemeaning that analysis of European film distribution, and to a lesser degree, exhibition, has been less visible. The focus of this chapter is therefore to offer an analysis of distribution policies that support the financing, production and circulation of European film, and underpin the circulation of co-productions.

\section{The European Circulation of European CO-PRODUCTIONS}

There were over 3200 European multi-national co-productions between 2007 and 2016, according to the Lumiere database (Talavera 2017, 27). In terms of European film, 24.2\% of European co-productions accounted for $50.3 \%$ of overall cinema admissions and generated three times as many cinema admissions as purely European national films (ibid., 3), perhaps not unexpectedly as these were often high budget productions. Consequently, overall European co-productions circulated almost twice as widely as solely national productions and in terms of distribution and exhibition, 39.5\% of the films produced in Europe between 2010 and 2015 received a theatrical release in a country other than the main production country (ibid., 51). For majority co-productions, this figure rises to $62.9 \%$, or 1464 films over the period (ibid.). Interestingly, despite EU incentives to co-produce with a European partner, $40 \%$ of the interactions with other countries in European majority co-productions were with non-European partners, who themselves are often enticed by being able to access European or national state subsidies and markets. Overall British, Danish, French and Irish co-productions travelled the most over the period 2010-2015, coming in above the EU average for foreign-release countries 
(6.74 countries), where the overall European average was 6.43 territories (ibid., 52).

The widest circulation reach is the UK where majority co-productions from producers - many wholly or partly owned subsidiaries of, or financed by, US companies - are far more widely released than national productions. Due to the many high-budget productions made with US producers-that are termed 'incoming investment productions' or 'GB inc'; films - a full $96 \%$ of UK majority co-productions received a release outside the UK (ibid., 52). For such 'GB inc' films, 78\% of the interactions were with non-European co-producers, mostly with US companies and therefore not official co-productions in terms of international co-production treaties (ibid., 29). On average, GB inc co-productions circulated in over 25 countries due to such linkages. This anomalous situation has allowed a number of films to be counted as British that might be considered Hollywood films, for instance the \$150 million Paramount picture Mission: Impossible-Rogue Nation (2015). Similarly a film such as Tinker, Tailer, Solder, Spy (2011) can be (and was) considered a European co-production even though its UK production company, Working Title, is a joint venture with a Hollywood major, NBC Universal. As such 'GB inc' productions skew the figures for European cinema, and rely on qualifying as European through the British 'cultural test' to access European and UK state support.

I have outlined data in this recent useful report as it demonstrates a range of tendencies in European co-productions, showing differences by territory, and also it establishes that co-productions tend to be more widely distributed than national productions. Not only that, but according to this report co-productions tend to also generate a higher number of cinema admissions than purely national films. Reasons for this are intuitive. Firstly, in terms of distribution, a co-production benefits from having producers and their knowledge in more than one country, helping to make domestic distribution more likely and more successful, especially as - in order to qualify as a co-production-certain elements of the story, location or above- and below-the-line talent are often able to connect with the domestic audiences of the countries involved in the project. Secondly, multinational co-productions are often higher-budget films involving financial contributions not easily raised in only one of the production countries, so by their very nature require international distribution and circulation. As Talavera pithily observes, 'since most co-productions reflect the fact that the project has greater prospects of reaching a more global or 
multi-regional audience, the fact that co-productions circulate better and gross more appears to be a self-fulfilling prophecy and not necessarily a recipe for success' $(2017,43)$. Clearly then, while the data is useful in identifying trends and tendencies it does not establish causality, nor can it simply be read as direct evidence to support European policies.

In terms of distribution, then, the picture is mixed and the European film market remains dominated-in terms of admissions and box-office receipts, but also in other windows-by Hollywood productions, albeit these are increasingly presented and masked as European co-productions. Hollywood films typically account for $70 \%$ of the European market, aided by vertically integrated structures spanning production and distribution, allowing them to offset risks/losses over a slate of films and to reinvest profits into new projects (Drake 2008; Katsarova 2014). Indeed the top distributors in Europe by market share are, year after year, subsidiaries of the Hollywood major studios followed by large European studios who operate on a similar basis (such as StudioCanal-see Christopher Meir's chapter in this volume). A 2014 European Parliament briefing outlines a number of structural weaknesses that prevent the EU film industry from reaching wider audiences, including barriers related to financing, the overwhelming focus on production (in a market characterised by over-supply) and limited attention to distribution and promotion (Katsarova 2014, 1). My aim in the rest of this chapter, then, is to place greater focus on the important area of distribution in European co-productions, and the policy instruments that support it; what we might call 'co-distributions'.

\section{How Does Film Distribution for Co-production}

\section{WORK?}

Distribution is the art of getting films to audiences. In Europe, distribution faces a number of challenges: linguistic diversity, different national film cultures and geographical boundaries around copyright and licensing. Co-productions are a key means not only to access finance and state aid for film production (such as through subsidies or tax rebates) across national borders but, as the data above indicates, they also help to increase distribution across European markets, or to help underwrite finance such that such access is made possible. For international co-productions, distribution rights in the territories of the participating nations are usually allocated to that national producer to sell; however, the rest of the world 
(ROW) rights are allocated according to negotiation, often related to overall contribution to financing. Producers sell rights through a segmented set of international release windows across each territory, aided by sales agents who attend international film markets—such as AFM, Berlin and Cannes-and aggregators, including sales for $\mathrm{VoD} /$ digital distribution (Smits 2018). Revenues are derived from theatrical, broadcast and home entertainment sales: cinema admission and traditionally Home Video/DVD/Blu-ray as well as broadcast rights, but now also video-ondemand (VoD)/Over-the-Top (OTT) services and digital download to own (DTO) services. Traditionally cinema and DVD windows have been followed by a primary broadcast window, then subsequent TV sales over a number of years, although as we shall examine, digital VoD services are disrupting such windowing strategies. Such market segmentation, windowing and amortisation of costs over time has historically been crucial to making most European films financially viable, as many only become profitable after their theatrical release, and the timing of windows has, over the past decade, been challenged from piracy, declining physical media sales and the rise of online viewing.

Key aspects of distribution involve negotiation of a pre-sale agreement-a contract between the producer and the distributor, whereby the distributor agrees to pay the producer a fixed advance/minimum guarantee (MG) upon completion, with a share of profit after deductions. In exchange, the distributor can sell the content in a given territory and/or window, often exclusively. Co-production deals are thus a means of raising additional finance and involve producers in different territories, jointly financing or producing films in return for an agreed proportion of the proceeds and/or the right to exploit the film in the various markets and windows. In this context, for many European films, the importance of national and supra-national film bodies and subsidies to European cinema cannot be overstated (Jones 2016). Many governments offer subsidies, rebates and additional funding to films that are produced in their territories, often with specific conditions such as the film being shot on location there, spending a proportion of its budget within that territory, or with stipulations about a percentage of spend being on domestic above-the-line talent or crew. Local production policies, such as city film offices, tend to replicate this, encouraging spend and inward investment within their locales through financial incentives and other logistics and locations support. 
As a number of writers have noted (Iordanova and Cunningham 2012; Cunningham and Silver 2013; Curtin et al. 2014), over the past decade the film value chain $(\mathrm{FVC})$ has undergone major disruption with changing patterns of consumption. In particular, the revenues for DVD have dramatically declined, and are only now being replaced in part by significant revenues from digital VoD and EST (Electronic Sell-through). Segmented windows and their timing allows differential pricing to audiences willing to pay for the content in different formats or settings, and at different times, though as the traditional distribution window has now significantly changed a new understanding of how to bring audiences to European films is required (Drake et al. 2015). In the latter part of this chapter, I consider European policy responses to such shifts towards digital distribution and online delivery.

\section{European Film Policies}

European film policies operate and take effect at a supranational, national, regional and sometimes city level by a range of policy actors. A number of scholars have observed that there is significant competition among European countries to use state aid to attract investment, especially inward investment for large-scale, mainly Hollywood/US, media production on location in Europe (Drake 2013; Donders et al. 2014; Liz 2016). This leads to a subsidy race that uses tax incentives to draw productions to a country and to obtain in return the employment of local film companies, cast and crew. However, a major criticism of such approaches is that such inward investment policies are a subsidy 'race to the bottom'. From a EU perspective, supporting non-EU productions may have indirect economic benefits (improving skills and infrastructure base); however, profits related to such productions do not necessarily flow back to the domestic industry. An example of this in the UK is the focus of state support towards a tax relief on eligible spend (introduced in 2007) that has led a large proportion of public funds supporting film being captured by Hollywood studiofunded runaway productions located in the UK, which-passing the 'cultural test' in terms of UK spend-are able to access UK public subsidies, principally a qualifying tax relief of $25 \%$ of $80 \%$ of spend (a $20 \%$ relief overall). Such a strategy does not align easily with the stated rationale of EU state aid policy, since such Hollywood films do not face the same problems of access to finance and distribution as European producers, and their access to such subsidies arguably offers only short-term benefits to 
the European film industry-for example in providing employment for a local skills and facilities base.

In 2013, the European Commission adopted revised rules-state support continues to be limited to $50 \%$ of the production budget; however, distribution and promotion costs may now also be supported (Katsarova $2014,5)$. This finally recognised the problem faced by European filmnot of levels of production, but of barriers to distribution and access to audiences. Furthermore, co-productions funded by more than one EU Member State can receive aid of up to $60 \%$ of the production budget, and these limits do not apply for script writing or film project development, or for 'difficult audiovisual works', as defined by each Member State, encouraging European co-production. Territorial spending obligations are still allowed but they cannot exceed $80 \%$ of the production budget (Katsarova $2014,5)$.

Some have argued that such state intervention leads to cultural homogenisation. For Dimitris Eleftheriotis, the term 'Euro-pudding' is used to describe a 'co-production that is determined by the necessities of funding rather than the desire of the makers to work together' $(2001,12)$. Others, such as Mariana $\operatorname{Liz}(2015,2016)$ take a more positive view, arguing that European initiatives have offered a much greater diversity of films than such a pejorative phrase would suggest. Liz's research on the socalled 'Euro-pudding' and European co-production initiatives interrogates such value judgements. She argues that a revised understanding of transnationalism is called for that avoids perpetuating outdated images of European cinema solely as a certain kind of art cinema ( $\operatorname{Liz} 2015,85)$.

I now wish to look at key support mechanisms for film distribution in Europe, focusing on Creative Europe's MEDIA programmes, which financially support distribution for European films. I will consider their justification and efficacy, before turning to a discussion of digital distribution policies. A number of important EU audiovisual polices were enacted from the late 1980s, helping to support the rise of the European coproduction. The first, Eurimages, was founded in 1988 by the Council of Europe and is a selective aid scheme that focuses mainly on co-production support. It has a relatively small budget: approximately $€ 25$ million per annum of which $90 \%$ funds co-productions (Katsarova 2014,6). The distribution support programme offered by Eurimages supports 37 of the 47 member states (membership does not include the UK), plus Canada as Associate member. Underpinning Eurimages, is, as film scholar Anna Jäckel notes, an overall aim to "promulgate "European values" and 
"identity" $(2015,62)$. As this scheme is primarily focused on co-production funding, rather than support for distribution, and is dealt with elsewhere in this volume, I will turn instead to the MEDIA programme, which supports film distribution.

\section{The MEDIA Programme}

The European Commission launched the MEDIA programme in 1987, as a three-year trial period focusing on skills development, marketing and distribution. Unlike Eurimages, the aim of the MEDIA programme was not to provide support for production costs. Instead, the MEDIA programme offers a significant policy framework in support of European film distribution aiming to increase the circulation of European films. The MEDIA programme has had numerous funding cycles-MEDIA I (1991-1995), MEDIA II (1996-2000), MEDIA Plus (2001-2006), and MEDIA 2007 (2007-2013) and now in its 2014-2020 iteration has seen its budget grow from $€ 200$ million for the period 1991-1996 to approximately $€ 800$ million for 2014-2020. The number of participating countries increased from 15 in 1991 to 23 in 2002 to 31 in 2007 and currently stands at 35 members. In 2014, it was controversially put under a larger umbrella of Creative Europe, part of the Education, Audiovisual and Culture Executive Agency (EACEA). Creative Europe has a total budget of $€ 1.46$ billion from 2014-2020, and brings together various actions under the MEDIA and the Culture programmes that aim to support the European cultural and creative sectors.

For distribution support, the MEDIA programme operates both 'Automatic' and 'Selective' funding schemes. The Automatic Scheme is a subsidy for theatrical distributors based on the number of paid cinema admissions in a previous calendar year for recent non-national European films. This scheme calculates the number of paying cinema admission tickets sold during the year for non-national European films in countries participating in the MEDIA sub-programme, up to a fixed ceiling per film and adjusted for each country. This fund must then be reinvested in either: (1) the co-production of non-national European films, (2) the acquisition of distribution rights, for example by means of minimum guarantees, of non-national European films, or (3) prints, dubbing and subtitling costs, promotion and publicity costs for non-national European films (Creative Europe Desk UK 2018). The Selective Scheme, on the other hand, directly supports the transnational distribution of European films. This funds 
groups of distributors (a minimum of seven per group in 2017) to release non-national films that it states 'might be a challenge were they to be supported by market forces alone' (Creative Europe Desk UK 2018). The aim of this support is to help European film audiences to gain access to a wider range of films. Approximately $25 \%$ of the budget is allocated to films with a production budget below $€ 3$ million, and grants fund distribution campaigns of non-national European films (awarding between $€ 2200$ and $€ 150,000$ to each distributor according to the number of screens covered on the first week of release).

In my following analysis, I am indebted to Huw Jones (2017) and the MeCETES project who provided me with an extracted dataset compiled from the European Audiovisual Observatory's Lumiere database and the European Commission. According to this dataset, during 2007-2013 coproductions accounted for $40 \%$ of the European film released with MEDIA distribution support and 53\% of the total MEDIA distribution budget in the period. Table 5.1 shows the number of films released in the EU in the period 2007-2013, and Table 5.2 those films with MEDIA theatrical distribution support. The numbers are further broken down by primary country-of-origin (i.e. the country which was the majority producer on the film) and production type (e.g. co-production, domestic production, inward investment). Table 5.3 shows the total amount of MEDIA theatrical distribution support each producing country received, and Table 5.4 is further broken down by Automatic and Selective funding for coproductions. While a full drilled-down analysis of the dataset is beyond the scope of this chapter (for this see Jones (forthcoming)), it is notable that co-productions are more likely to receive MEDIA distribution support than domestic features. In the period 2007-2013, 24.2\% of European films were co-productions (2110-Table 5.1), yet, co-productions accounted for over $40 \%$ of European films released with MEDIA distribution support ( 591 out of 1473 films-Table 5.2 ) and for $53 \%$ of the total MEDIA distribution budget (€107,093 million out of a total €201,046 million-Tables 5.3 and 5.4). The larger producing nations were also the largest beneficiaries of MEDIA distribution support, especially in terms of monetary value, led by France (FR) with $€ 66,278$ million, followed by the $\mathrm{UK}(\mathrm{GB})$ at $€ 39,445$ million and Germany (DE) a distant third at $€ 20,391$ million). However, Italy (IT), the second largest producing nation in numbers of films (917) after France (1611) during the period, only received $€ 11,331$ millions of support, or fourth ranking, a reflection of either the lower budget level of films produced or a narrower distribution 
t1.1 Table 5.1 European film releases by country (2007-2013)

\begin{tabular}{|c|c|c|c|c|c|}
\hline $\mathrm{t} 1.2$ & Number of films released & & & & \\
\hline $\mathrm{t} 1.3$ & Primary country-of-origin & $C O P$ & $D O M$ & $I N C$ & All films \\
\hline $\mathrm{t} 1.4$ & AT & 62 & 146 & 0 & 208 \\
\hline $\mathrm{t} 1.5$ & $\mathrm{BE}$ & 95 & 103 & 0 & 198 \\
\hline $\mathrm{t} 1.6$ & BG & 11 & 48 & 0 & 59 \\
\hline $\mathrm{t} 1.7$ & $\mathrm{CH}$ & 103 & 340 & 0 & 443 \\
\hline $\mathrm{t} 1.8$ & $\mathrm{CY}$ & 1 & 0 & 0 & 1 \\
\hline $\mathrm{t} 1.9$ & $\mathrm{CZ}$ & 38 & 242 & 0 & 280 \\
\hline $\mathrm{t} 1.10$ & $\mathrm{DE}$ & 236 & 640 & 0 & 876 \\
\hline $\mathrm{t} 1.11$ & DK & 48 & 140 & 0 & 188 \\
\hline $\mathrm{t} 1.12$ & $\mathrm{EE}$ & 26 & 79 & 0 & 105 \\
\hline $\mathrm{t} 1.13$ & ES & 160 & 707 & 0 & 867 \\
\hline $\mathrm{t} 1.14$ & FI & 51 & 129 & 0 & 180 \\
\hline $\mathrm{t} 1.15$ & FR & 494 & 1117 & 0 & 1611 \\
\hline $\mathrm{t} 1.16$ & GB & 219 & 611 & 66 & 896 \\
\hline $\mathrm{t} 1.17$ & GR & 7 & 30 & 0 & 37 \\
\hline $\mathrm{t} 1.18$ & HR & 10 & 30 & 0 & 40 \\
\hline $\mathrm{t} 1.19$ & $\mathrm{HU}$ & 30 & 97 & 0 & 127 \\
\hline $\mathrm{t} 1.20$ & IE & 39 & 38 & 1 & 78 \\
\hline $\mathrm{t} 1.21$ & IS & 10 & 18 & 0 & 28 \\
\hline $\mathrm{t} 1.22$ & IT & 150 & 767 & 0 & 917 \\
\hline $\mathrm{t} 1.23$ & LI & 1 & 0 & 0 & 1 \\
\hline $\mathrm{t} 1.24$ & $\mathrm{LT}$ & 8 & 33 & 0 & 41 \\
\hline $\mathrm{t} 1.25$ & LU & 12 & 0 & 0 & 12 \\
\hline $\mathrm{t} 1.26$ & LV & 9 & 38 & 0 & 47 \\
\hline $\mathrm{t} 1.27$ & NL & 53 & 271 & 0 & 324 \\
\hline $\mathrm{t} 1.28$ & $\mathrm{NO}$ & 37 & 163 & 0 & 200 \\
\hline $\mathrm{t} 1.29$ & PL & 29 & 195 & 0 & 224 \\
\hline $\mathrm{t} 1.30$ & PT & 26 & 107 & 0 & 133 \\
\hline $\mathrm{t} 1.31$ & RO & 30 & 76 & 0 & 106 \\
\hline $\mathrm{t} 1.32$ & SE & 77 & 292 & 0 & 369 \\
\hline $\mathrm{t} 1.33$ & SI & 13 & 37 & 0 & 50 \\
\hline $\mathrm{t} 1.34$ & SK & 25 & 48 & 0 & 73 \\
\hline $\mathrm{t} 1.35$ & Total & 2110 & 6542 & 67 & 8719 \\
\hline
\end{tabular}

t1.36 Source: Jones (2017). Analysis based on MeCETES data from Lumiere/European Audiovisual t1.37 Observatory (European territories) and the European Commission

t1.38 Sources of data: Primary county of origin: Lumiere (http://lumiere.obs.coe.int/web/iso_codes/)

t1.39 MEDIA funded: European Commission

t1.40 COP-Co-production

t1.41 DOM-Domestic or $100 \%$ national production

t1.42 INC-Incoming investment film 
Table 5.2 European film releases with MEDIA theatrical support by country t2.1 (2007-2013)

\begin{tabular}{|c|c|c|c|c|}
\hline Primary country-of-origin & $C O P$ & $D O M$ & $I N C$ & All films \\
\hline AT & 18 & 15 & 0 & 33 \\
\hline $\mathrm{BE}$ & 31 & 15 & 0 & 46 \\
\hline BG & 1 & 1 & 0 & 2 \\
\hline $\mathrm{CH}$ & 14 & 13 & 0 & 27 \\
\hline CY & 0 & 0 & 0 & 0 \\
\hline $\mathrm{CZ}$ & 11 & 36 & 0 & 47 \\
\hline $\mathrm{DE}$ & 70 & 138 & 0 & 208 \\
\hline DK & 20 & 33 & 0 & 53 \\
\hline $\mathrm{EE}$ & 1 & 2 & 0 & 3 \\
\hline ES & 25 & 54 & 0 & 79 \\
\hline FI & 8 & 11 & 0 & 19 \\
\hline FR & 189 & 297 & 0 & 486 \\
\hline GB & 66 & 81 & 14 & 161 \\
\hline GR & 1 & 5 & 0 & 6 \\
\hline $\mathrm{HR}$ & 1 & 0 & 0 & 1 \\
\hline $\mathrm{HU}$ & 4 & 4 & 0 & 8 \\
\hline IE & 11 & 5 & 1 & 17 \\
\hline IS & 4 & 5 & 0 & 9 \\
\hline IT & 41 & 51 & 0 & 92 \\
\hline LI & 0 & 0 & 0 & 0 \\
\hline LT & 0 & 1 & 0 & 1 \\
\hline LU & 3 & 0 & 0 & 3 \\
\hline LV & 1 & 0 & 0 & 1 \\
\hline NL & 8 & 10 & 0 & 18 \\
\hline NO & 12 & 34 & 0 & 46 \\
\hline PL & 6 & 12 & 0 & 18 \\
\hline PT & 8 & 1 & 0 & 9 \\
\hline RO & 12 & 9 & 0 & 21 \\
\hline SE & 21 & 30 & 0 & 51 \\
\hline SI & 1 & 1 & 0 & 2 \\
\hline SK & 3 & 3 & 0 & 6 \\
\hline Total & 591 & 867 & 15 & 1473 \\
\hline
\end{tabular}

Source: Jones (2017). Analysis based on MeCETES data from Lumiere/European Audiovisual 
94 P. DRAKE

t3.1 Table 5.3 European films supported by the MEDIA programme by country t3.2 (2007-2013) in euros

\begin{tabular}{|c|c|c|c|c|}
\hline \multirow{2}{*}{$\begin{array}{l}\text { t3.3 } \\
\text { t3.4 }\end{array}$} & \multirow[t]{2}{*}{ Primary country-of-origin } & \multicolumn{3}{|c|}{ All films } \\
\hline & & Automatic & Selective & MEDIA \\
\hline $\mathrm{t} 3.5$ & AT & $€ 1,305,900$ & $€ 2,697,660$ & $€ 4,003,560$ \\
\hline $\mathrm{t} 3.6$ & $\mathrm{BE}$ & $€ 5,926,666$ & $€ 2,864,200$ & $€ 8,790,866$ \\
\hline $\mathrm{t} 3.7$ & BG & $€ 50,358$ & $€ 178,000$ & $€ 228,358$ \\
\hline $\mathrm{t} 3.8$ & $\mathrm{CH}$ & $€ 959,892$ & $€ 518,000$ & $€ 1,477,892$ \\
\hline $\mathrm{t} 3.9$ & $\mathrm{CY}$ & & & $€-$ \\
\hline $\mathrm{t} 3.10$ & $\mathrm{CZ}$ & $€ 735,542$ & $€ 466,500$ & $€ 1,202,042$ \\
\hline $\mathrm{t} 3.11$ & $\mathrm{DE}$ & $€ 13,180,959$ & $€ 7,210,100$ & $€ 20,391,059$ \\
\hline $\mathrm{t} 3.12$ & DK & $€ 3,855,290$ & $€ 6,730,050$ & $€ 10,585,340$ \\
\hline $\mathrm{t} 3.13$ & $\mathrm{EE}$ & $€ 23,840$ & $€ 210,900$ & $€ 234,740$ \\
\hline $\mathrm{t} 3.14$ & ES & $€ 7,953,337$ & $€ 3,330,250$ & $€ 11,283,587$ \\
\hline $\mathrm{t} 3.15$ & FI & $€ 1,331,004$ & $€ 1,903,250$ & $€ 3,234,254$ \\
\hline $\mathrm{t} 3.16$ & FR & $€ 45,974,842$ & $€ 20,303,600$ & $€ 66,278,442$ \\
\hline $\mathrm{t} 3.17$ & GB & $€ 26,216,655$ & $€ 13,229,150$ & $€ 39,445,805$ \\
\hline t3.18 & GR & $€ 153,254$ & $€ 464,500$ & $€ 617,754$ \\
\hline $\mathrm{t} 3.19$ & HR & $€ 1800$ & $€ 128,000$ & $€ 129,800$ \\
\hline $\mathrm{t} 3.20$ & $\mathrm{HU}$ & $€ 62,534$ & $€ 287,600$ & $€ 350,134$ \\
\hline $\mathrm{t} 3.21$ & IE & $€ 1,310,178$ & $€ 1,723,300$ & $€ 3,033,478$ \\
\hline $\mathrm{t} 3.22$ & IS & $€ 172,452$ & $€ 394,200$ & $€ 566,652$ \\
\hline $\mathrm{t} 3.23$ & IT & $€ 5,570,905$ & $€ 5,761,000$ & $€ 11,331,905$ \\
\hline $\mathrm{t} 3.24$ & LI & & & $€-$ \\
\hline $\mathrm{t} 3.25$ & LT & $€ 8409$ & & $€ 8409$ \\
\hline $\mathrm{t} 3.26$ & LU & $€ 142,175$ & & $€ 142,175$ \\
\hline $\mathrm{t} 3.27$ & LV & $€ 7680$ & & $€ 7680$ \\
\hline $\mathrm{t} 3.28$ & NL & $€ 399,716$ & $€ 228,500$ & $€ 628,216$ \\
\hline $\mathrm{t} 3.29$ & $\mathrm{NO}$ & $€ 2,258,088$ & $€ 2,252,950$ & $€ 4,511,038$ \\
\hline $\mathrm{t} 3.30$ & PL & $€ 582,988$ & $€ 755,800$ & $€ 1,338,788$ \\
\hline $\mathrm{t} 3.31$ & PT & $€ 92,199$ & $€ 335,700$ & $€ 427,899$ \\
\hline $\mathrm{t} 3.32$ & RO & $€ 561,320$ & $€ 2,406,250$ & $€ 2,967,570$ \\
\hline $\mathrm{t} 3.33$ & SE & $€ 5,306,630$ & $€ 2,196,900$ & $€ 7,503,530$ \\
\hline $\mathrm{t} 3.34$ & SI & $€ 8832$ & $€ 84,500$ & $€ 93,332$ \\
\hline $\mathrm{t} 3.35$ & SK & $€ 148,137$ & $€ 84,500$ & $€ 232,637$ \\
\hline $\mathrm{t} 3.36$ & Total & $€ 124,301,582$ & $€ 76,745,360$ & $€ 201,046,942$ \\
\hline
\end{tabular}

t3.37 Source: Jones (2017). Analysis based on MeCETES data from Lumiere/European Audiovisual t3.38 Observatory (European territories) and the European Commission 
Table 5.4 European co-productions supported by the MEDIA programme by t4.1 country (2007-2013) in euros

\begin{tabular}{|c|c|c|c|c|}
\hline \multirow[t]{2}{*}{ Primary country-of-origin } & \multicolumn{3}{|c|}{$C O P$} & $\mathrm{t} 4.3$ \\
\hline & Automatic & Selective & $M E D I A$ & $\mathrm{t} 4.4$ \\
\hline AT & $€ 752,920$ & $€ 1,843,660$ & $€ 2,596,580$ & $\mathrm{t} 4.5$ \\
\hline $\mathrm{BE}$ & $€ 4,741,546$ & $€ 2,864,200$ & $€ 7,605,746$ & $\mathrm{t} 4.6$ \\
\hline BG & $€ 34,158$ & $€ 178,000$ & $€ 212,158$ & $\mathrm{t} 4.7$ \\
\hline $\mathrm{CH}$ & $€ 455,262$ & $€ 448,000$ & $€ 903,262$ & $\mathrm{t} 4.8$ \\
\hline $\mathrm{CY}$ & & & $€-$ & $\mathrm{t} 4.9$ \\
\hline $\mathrm{CZ}$ & $€ 151,295$ & $€ 362,500$ & $€ 513,795$ & $\mathrm{t} 4.10$ \\
\hline $\mathrm{DE}$ & $€ 5,975,932$ & $€ 4,355,600$ & $€ 10,331,532$ & $\mathrm{t} 4.11$ \\
\hline DK & $€ 2,709,026$ & $€ 5,648,450$ & $€ 8,357,476$ & $\mathrm{t} 4.12$ \\
\hline $\mathrm{EE}$ & $€ 19,340$ & $€ 143,400$ & $€ 162,740$ & $\mathrm{t} 4.13$ \\
\hline ES & $€ 1,652,420$ & $€ 1,568,250$ & $€ 3,220,670$ & $\mathrm{t} 4.14$ \\
\hline FI & $€ 1,094,298$ & $€ 1,549,250$ & $€ 2,643,548$ & $\mathrm{t} 4.15$ \\
\hline FR & $€ 22,117,145$ & $€ 9,854,350$ & $€ 31,971,495$ & $\mathrm{t} 4.16$ \\
\hline GB & $€ 14,534,939$ & $€ 5,402,750$ & $€ 19,937,689$ & $\mathrm{t} 4.17$ \\
\hline GR & $€ 42,342$ & $€ 218,000$ & $€ 260,342$ & $\mathrm{t} 4.18$ \\
\hline $\mathrm{HR}$ & $€ 1800$ & $€ 128,000$ & $€ 129,800$ & $\mathrm{t} 4.19$ \\
\hline $\mathrm{HU}$ & $€ 24,958$ & $€ 287,600$ & $€ 312,558$ & $\mathrm{t} 4.20$ \\
\hline IE & $€ 860,351$ & $€ 448,500$ & $€ 1,308,851$ & $\mathrm{t} 4.21$ \\
\hline IS & $€ 67,109$ & $€ 160,000$ & $€ 227,109$ & $\mathrm{t} 4.22$ \\
\hline IT & $€ 3,030,573$ & $€ 2,404,400$ & $€ 5,434,973$ & $\mathrm{t} 4.23$ \\
\hline LI & & & $€-$ & $\mathrm{t} 4.24$ \\
\hline LT & & & $€-$ & $\mathrm{t} 4.25$ \\
\hline LU & $€ 142,175$ & & $€ 142,175$ & $\mathrm{t} 4.26$ \\
\hline LV & $€ 7680$ & & $€ 7680$ & $\mathrm{t} 4.27$ \\
\hline NL & $€ 75,777$ & $€ 228,500$ & $€ 304,277$ & $\mathrm{t} 4.28$ \\
\hline $\mathrm{NO}$ & $€ 1,271,221$ & $€ 1,044,700$ & $€ 2,315,921$ & t4.29 \\
\hline PL & $€ 335,266$ & $€ 369,600$ & $€ 704,866$ & $\mathrm{t} 4.30$ \\
\hline PT & $€ 79,709$ & $€ 335,700$ & $€ 415,409$ & $\mathrm{t} 4.31$ \\
\hline $\mathrm{RO}$ & $€ 301,264$ & $€ 1,362,300$ & $€ 1,663,564$ & $\mathrm{t} 4.32$ \\
\hline SE & $€ 3,755,504$ & $€ 1,448,600$ & $€ 5,204,104$ & $\mathrm{t} 4.33$ \\
\hline SI & & $€ 84,500$ & $€ 84,500$ & $\mathrm{t} 4.34$ \\
\hline SK & $€ 120,529$ & & $€ 120,529$ & $\mathrm{t} 4.35$ \\
\hline Total & $€ 64,354,539$ & $€ 42,738,810$ & $€ 107,093,349$ & $\mathrm{t} 4.36$ \\
\hline
\end{tabular}

Source: Jones (2017). Analysis based on MeCETES data from Lumiere/European Audiovisual Observatory (European territories) and the European Commission 
strategy. Indeed, in terms of overall MEDIA distribution funding, after France, UK and Germany, the next highest levels of financial support for nations were $€ 10-11$ million (Italy, Spain (ES), Denmark (DK) and under.

For co-production distribution funding, the largest support for nations (determined by primary country of origin-major producer) were France at $€ 31,971$ million, the UK at $€ 19,937$ million and Germany at $€ 10,331$ million, showing that distribution support for co-productions accounts for approximately $50 \%$ of total MEDIA distribution support in these nations. The UK (GB inc) productions, as noted above, also included incoming investment from external partners, very often from a US company that controls or partially owns a UK film subsidiary or partner). This is quite unlike most other European nations, with GB inc accounting for 66 from 67 of such film releases from 2007-2013 and 14 (from a total 15) of them supported by funding from the MEDIA programme. In terms of the balance between Automatic and Selective support, the majority (61.8 $\%)$ of MEDIA funds went to Automatic support, totalling $€ 124,301$ million from $€ 201,046$ million. Again the largest beneficiaries were France and the UK, which together obtained $53 \%$ of the total distribution support from the MEDIA programme's distribution support budget. A slightly lower percentage, $48.5 \%$, was obtained by these two countries for their co-production support, although again they were by far the largest financial beneficiaries of the policies.

Liz (2016) offers a useful analysis of the overall philosophy of the MEDIA programme, in particular the duality of its policies: designed to both make a more competitive industry, and give a European character to the sector's output. In Liz's interviews with EU policy-makers participants asked for their responses to remain anonymous; noting that the gap between official discourse and the interviewees' views is clearly a reason for this request for anonymity' $(2016,8)$. Such a finding is not unusual in policy research - my own research with film policy-makers and film-makers demonstrated a similar gap which sometimes demonstrated a tension between official and tacit understandings of how policies and funding frameworks operate (Drake 2013; Drake et al. 2015).

In addition to the MEDIA programme, a range of other support for European film distribution is available. Examples of this would be distribution support from the Centre National du Cinéma et de l'Image Animée (CNC) and the Institut Français to promote the distribution and international circulation of ACM (Aide aux cinemas du monde) films co-produced by France. In this scheme, distribution must cover at least three territories, 
one of which must be European (excluding France), and one from outside of Europe. Similarly the Berlinale World Cinema Fund Europe supports distribution of films from Latin America, Central America, the Caribbean, Africa, the Middle East, Central Asia, Southeast Asia and countries of the former USSR excluding the Baltic Region and Russia. Interestingly, in 2018 a new MEDIA support programme has been launched called Cinema Networks 2019 that will subsidise groups of at least 100 cinemas operating in 20 countries showing European films, with the objective of promoting transnational circulation (EACEA/06/2018: Support to Cinema Networks). This would presumably sit alongside the current Europa Cinema Network, which comprises over 2000 screens across 32 countries and claims to attract 60 million spectators annually (representing around $5 \%$ of total European film admissions) (Wutz and Pérez 2014,7).

Finally, it is worth noting an initiative of the European Parliament-the LUX Prize-which has been awarded annually since 2007. The prize supports the circulation of European co-productions and aims at overcoming the language and distribution barriers for European films (Katsarova 2014, 8). The LUX Prize is focused on distribution and the winner does not receive a direct grant but instead the costs of wider distribution, and the three films in competition are subtitled in the 24 official EU languages and are screened in more than 40 cities and at 18 festivals (Stjernholm 2016). Jäckel (2015) has examined the recent history of sponsored European co-productions to question the cultural homogenisation 'Europudding' accusation outlined earlier, arguing that awards both helped to construct a European identity but ironically they also foregrounded European cultural diversity and opposition to European homogeneity.

As I have outlined, European support for distribution is highly significant and the MEDIA programme in particular has provided an important means for European co-productions to access funds towards wider distribution. However, it is unclear how effective these support mechanisms have been and whether they tend to cluster, as the data suggests, around the larger European film industries at the expense of smaller nations and industries. While the support levels are significant, they are only one element in the larger picture of European film financing and distribution, which includes national state policies (mostly focused on supporting production), as well as the challenge of building European audiences in markets dominated by Hollywood films and distributors. Furthermore, cinema exhibition has to compete with other windows, including the rise of film 
viewing on digital, on-demand and VoD services. I will now consider how European film policies have started to address this issue.

\section{Digital Distribution and European Film Policies: Walk This Way (WTW) and The TIDE Experiment}

European film policies such as the MEDIA programme and Eurimages tend to focus on traditional forms of distribution rather than emerging models and opportunities for digital distribution. Yet digital distribution has the potential to reach additional audiences across a range of platforms and to engage new audiences for films (Crusafon 2015; De Vinck and Pauwels 2015; Drake et al. 2015; Kehoe and Mateer 2015). I will look at recent EU attempts to offer policy support for digital distribution of European Film. According to a 2017 EU report, European films are less widely distributed on VoD than US films: on average, EU films are available in 2.8 countries, US films in 6.8 countries. However, in cinemas, European co-productions circulate better than national films and on average, EU co-productions are available in 3.6 countries (Grece 2017, 4). As a response to such challenges Europe has attempted some policy subventions. Funded by Creative Europe, Walk This Way (WtW) is described as a scheme to support European producers 'looking to address the challenges of the digital era by coordinating experimentations on new economic models for digital films distribution' (Creative Europe 2018). It manages the pan-European release of a catalogue of films on VoD platforms in Europe and in its second 2016 edition, it uses the digital distributor/aggregator Under The Milky Way and The Film Agency (a marketing company) to release 50 European films in partnership with production companies, including Autlook Filmsales (AT), Beta films (DE), Memento films (FR), The Yellow Affair (FI), Celluloid Dreams (FR) and New Europe film sales (PL). These are presented to pan-European platforms such as iTunes, Amazon and Google Play, as well as local VoD platforms aiming to increase exposure, coverage, availability and reach European audiences. In addition a digital marketing and promotion campaign aims to generate sales, both on a territory-by-territory basis and on what it terms a 'transversal level' (Creative Europe 2018). In its somewhat hyperbolic prose, $\mathrm{WtW}$ describes itself as a: 
experimentations and develops sustainable innovative business models to support the EU film industry's competitiveness. We are convinced that digital distribution represents a unique opportunity for the European film industry to go beyond frontiers and meet the Digital Single Market objectives like providing the EU audience with "More choice with greater access to content, goods and services from EU countries”. (Creative Europe 2018)

In 2016, WtW provided digital VOoD distribution for 44 films from 13 443 European Union countries (Caranicas 2017). In 2017, it received a further grant of 1.17 million euro. In an interview reported in Variety, Vincent Lucassen, president of the Independent Pan-European Digital Association (IPEDA) stated that the challenge for WtW 'is to convert clicks to sales' (ibid.). However, despite their hyperbolic sales pitch, and funding, concrete evaluation of such European VoD support schemes is currently lacking. Without viewing data analytics, and costings, it is impossible to evaluate whether $\mathrm{WtW}$ has succeeded in its aims to support wider release or to evaluate the sustainability of the new business models it is trialling.

Similarly, the European Commission has attempted to support new patterns of release, as described earlier. The TIDE Experiment provides a framework to facilitate quasi-simultaneous (Day-and-Date) releases of European films on multiple platforms in different EU territories, using shared material and marketing tools. Running annually since 2012, the current iteration, TIDE 5 is supported by the European Commission's Preparatory action and the MEDIA programme. In addition to the Dayand-Date model, TIDE also experiments, since 2015, with Festival-toDate releases, where films are simultaneously released in festivals and on VoD platforms. According to its guidelines, it has five main objectives: (1) Strengthen the experimentation of D\&D releases in the most suitable markets. (2) Develop the Festival-to-Date scheme, which enables outreach to new types of audiences and films. (3) Continue to support each release with specific promotion and marketing actions adapted to the audience targeted both at local and transversal levels. (4) Continue the work of collecting and organising data sharing systems with stakeholders in the European film industry. Again in hyperbolic prose, the TIDE experiment describes itself as 'a sustainable, collaborative, concrete and transparent answer for the European Film Industry that is longing for new digital forms of distribution, promotion and business models' (Creative Europe 2018). 
As with $\mathrm{WtW}$, evidence for the efficacy of this policy instrument in relation to the stated objectives is lacking. In a report from 2015 analysing nine of the film releases, Thomas Paris offers a useful analysis of these 'preparatory actions' but avoids making a judgement over this, stating:

the purpose of this report was not to declare these experiments as successes or failures. In a context where the cinema industry's economics and practices are undergoing profound transformation, the purpose of these experiments is to better understand the changes taking place, and especially to better anticipate the factors which determine complementarity between different distribution channels. The quantitative results of these experiments remain modest (Paris et al. 2015, 50).

However, the report makes a number of useful findings that broadly chime with my own research on VoD (Drake et al. 2015): firstly, that simultaneous release on VoD widens the potential audience for the films, supporting access in remote areas where there is no cinema release, hence 'Day\&Date releases are a factor in reducing the real cinematographic divide' (Paris et al. 2015, 50). It also suggests that the different kinds of films have different potential to be released in this way-that some films have 'high potential on a national, or even European scale, but insufficient local potential for in-theatre showings' (Paris et al. 2015, 50). This suggests that VoD release can help certain films reach pan-European audiences that would otherwise be inaccessible. Attempts to understand and support this emerging market continue., In 2015 Curzon Film World received a grant of $€ 345,000$ to experiment with the simultaneous release in 2016 of $\mathrm{Il}$ racconto dei racconti/Tale of Tales (2015) across multiple platforms. The Promotion of European Audiovisual Works Online scheme was launched in 2016, in addition to the above schemes, funding 37 projects selected across Europe sharing grants totalling $€ 9,462,504$. Beneficiaries include a range of European VoD platforms including MUBI, Curzon Home Cinema and OutTV (Creative Europe 2018).

\section{Conclusions}

The aim of this chapter has been to explore the relationship between European co-production and distribution, and examine European policies designed to support film distribution including, more recently, digital and VoD film distribution. I have argued that most focus has been placed on 
production and co-production, and evidence-based analysis of European film distribution has been lacking, especially in terms of VoD release. Moreover, I have presented a critical evaluation of distribution policies for co-productions in Europe, and of support mechanisms such as Creative Europe's MEDIA programmes. I have also examined the prevalence of different approaches to support, including the automatic and selective distribution schemes under the MEDIA programme.

Overall analysis suggests that European policy-supported films, among them many co-productions, are distributed and circulate more widely than national productions. However, as co-productions tend to be higher-profile films, it is not clear that the effect of subsidies/policy subventions can be disaggregated from the overall performance of films. The key issue remains demand-audiences across Europe have access to European films, yet more often than not they choose not to see them, whether in the cinema, on television or on VoD. Clearly emerging models for digital distribution of films offer the potential to reach additional audiences across a range of platforms, and could be a solution to the problem by extending reach of those films, potentially offering European films greater visibility. However, as my analysis of support for digital distribution via VoD and Day-andDate release has shown, presently there is insufficient evidence to conclude whether such potential can be realised, and increasing dominance of major providers Netflix and Amazon Video in the European VoD market suggests that other forms of regulation might need consideration. Proposals towards a European Digital Single Market will also impact on film distribution business models, and-as the chapter by Nina Vindum Rasmussen in this volume outlines-many in the industry have argued that such harmonisation could damage the viability of smaller film industries by allowing large distributors to dominate a pan-European market for film rights.

In closing, I will raise two issues for further consideration. As the second largest film market in the EU, and a major beneficiary of EU support, the UK's 2016 referendum decision to leave the European Union raises as yet unanswered questions about the impact that leaving will have on film production, distribution and exhibition across Europe. Potentially sitting outside European policy frameworks will likely change a number of factors for the UK, not only in altering UK producers' ability to participate in European co-productions, but also in potentially removing a significant European film industry from the European Digital Single Market. The second issue is that throughout this chapter I have discussed distribution

509

510

511

512

513

514

515

516

517

518

519

520

521

522

523

524

525

526

527

528

529

530

531

532

533

534

535

536

537

538

539

540

541

542

543

544

545

546

547 
in terms of formal distribution; however, a full analysis of film distribution must also consider informal circulation channels such as consumption of pirated content (Lobato 2012; Crisp 2015) and as such the audience for European films may indeed be considerably more substantial and diverse than the official figures for formal distribution suggest.

\section{REFERENCES}

Caranicas, Peter. 2017. European Digital Initiatives Offer New Paths for Distributing Indie Films. Variety, July 4. Accessed October 15, 2017. http:// variety.com/2017/digital/news/europe-digital-initiatives-distribution-indiefilms-1202487219/.

Creative Europe. 2018. Call for Proposals EACEA 28/2015: Summary of Selected Projects. http://www.creativeeurope.be/sites/creativeeurope/files/media/ online_distribution_projecten_eacea_28_2015.pdf.

Crisp, Virginia. 2015. Film Distribution in the Digital Age: Pirates and Professionals. London: Palgrave Macmillan.

Crusafon, Carmina. 2015. The European Audiovisual Space: How European Media Policy Has Set the Pace of Its Development. In European Film and Television: Cultural Policy and Everyday Life, ed. Ib Bondebjerg, Eva Novrup Redvall, and Andrew Higson, 81-101. Basingstoke: Palgrave Macmillan.

Cunningham, Stuart, and Jon Silver, eds. 2013. Screen Distribution and the New King-Kongs of the Online World. Basingstoke: Palgrave Macmillan.

Curtin, Michael, Jennifer Holt, and Kevin Sanson, eds. 2014. Distribution Revolution: Conversations about the Digital Future of Film and Television. Berkeley: University of California Press.

De Vinck, Sophie, and Caroline Pauwels. 2015. Beyond Borders and into the Digital Era: Future-proofing European-level Film Support Schemes. In European Film and Television: Cultural Policy and Everyday Life, ed. Ib Bondebjerg, Eva Novrup Redvall, and Andrew Higson, 102-126. Basingstoke: Palgrave Macmillan.

Donders, Karen, Caroline Pauwels, and Jan Loisen, eds. 2014. The Palgrave Handbook of European Media Policy. Basingstoke: Palgrave.

Drake, Philip. 2008. Distribution and Marketing in Contemporary Hollywood. In The Contemporary Hollywood Film Industry, ed. Paul McDonald and Janet Wasko, 63-82. Oxford and New York: Wiley.

- 2013. Policy or Practice? Deconstructing the Creative Industries. In Behind the Screen: Inside European Production Cultures, ed. Petr Szczepanik and Patrick Vonderau. New York: Palgrave Macmillan.

Drake, Philip, Michael Franklin, Deborah Sathe, and Sarah Tierney. 2015. We Are Colony: Digital VOD Distribution for Independent Film. London: Nesta. 
Eleftheriotis, Dimitris. 2001. Popular Cinemas of Europe: Studies of Texts, Contexts and Frameworks. London: Continuum.

Grece, Christian. 2017. Trends in the EU SVOD Market. European Audiovisual Observatory (Council of Europe), Strasbourg. Accessed 18 January 2018. https://rm.coe.int/trends-in-the-eu-svod-market-nov-2017/16807899ab.

Iordanova, Dina, and Stuart Cunningham, eds. 2012. Digital Disruption: Cinema Moves On-line. St Andrews: St Andrews Film Studies.

Jäckel, Anne. 2015. Changing the Image of Europe? The Role of European Co-Productions, Funds and Film Awards. In The Europeanness of European Cinema: Identity, Meaning, Globalization, ed. Mary Harrod, Mariana Liz, and Alissa Timoshkina, 59-72. London: I.B. Tauris.

Jones, Huw David. 2016. The Cultural and Economic Implications of UK/ 597 European Co-production. Transnational Cinemas 7 (1): 1-20.

—. 2017. Extracts from MeCETES Film Database [database]. Unpublished data from LUMIERE/European Audiovisual Observatory (European Territories) and the European Commission.

— forthcoming. Transnational European Cinema: Cross-Border Circulation and Reception. Cham: Palgrave Macmillan.

Katsarova, Ivana. 2014. An Overview of Europe's Film Industry. European 604 Parliamentary Research Service. Accessed 1 January 2018. http://www. europarl.europa.eu/RegData/etudes/BRIE/2014/545705/EPRS_ BRI(2014)545705_REV1_EN.pdf.

Kehoe, Keith, and John Mateer. 2015. The Impact of Digital Technology on the Distribution Value Chain Model of Independent Feature Films in the UK. International Journal on Media Management 17: 93-108.

Liz, Mariana. 2015. From Co-production to the Euro-pudding. In The Europeanness of European Cinema: Identity, Meaning, Globalization, ed. Mary Harrod, Mariana Liz, and Alissa Timoshkina, 73-86. London: I.B. Tauris.

- 2016. Euro- Visions: Europe in Contemporary Cinema. London: Bloomsbury.

615

Lobato, Ramon. 2012. Shadow Economies of Cinema. London: BFI Palgrave.

Paris, Thomas, Lucie Girre, Asmit Jain, and Aurélia Porret. 2015. New Approaches 618 for Greater Diversity of Cinema in Europe? Analyses of Experiments Launched in the Context of the Preparatory Action 'Circulation of Films in the Digital Era'. European Parliament and European Commission. Accessed 14 February 2018. http://ec.europa.eu/assets/eac/culture/library/studies/cinema-diversity-report_en.pdf.

Smits, Roderik. 2018. Tournaments of Values at the European Film Market. Arts and the Market. https://doi.org/10.1108/AAM-01-2018-0001. 19-31. 
104 P. DRAKE

629 Talavera, Julio. 2017. Film Production in Europe-Production Volume, 630 Co-production and Worldwide Circulation. Strasbourg: European Audiovisual 631 Observatory. Accessed 14 February 2018. https://rm.coe.int/film-produc632 tion-in-europe-2017/168078798c.

633 Wutz, Josef, and Valentin Pérez. 2014. Dissemination of European Cinema in the 634 European Union and the International Market. Paris: Jacque Delors Institute. 


\section{Author Queries}

Chapter No.: $5 \quad 0004181151$

\begin{tabular}{|l|l|l|}
\hline Queries & Details Required & Author's Response \\
\hline AU1 & $\begin{array}{l}\text { Please check if the reference details for ref. "Creative } \\
\text { Europe 2018" is fine in the reference list. Also advise if } \\
\text { any changes required in text. }\end{array}$ & \\
\hline AU2 & Please update year of publishing, if published. & \\
\hline
\end{tabular}

